\title{
UDC 334.004.9
}

\section{IT-TOOLS FOR OPTIMIZATION OF BUSINESS PROCESSES IN STARTUP PROJECTS}

\section{ІТ-ІНСТРУМЕНТИ ОПТИМІЗАЦІЇ БІЗНЕС-ПРОЦЕСІВ В СТАРТАП-ПРОЕКТАХ \\ Chuprina M.O. / Чупріна M.O. \\ Ph.D., assistant prof. / к.е.н., доиент ORCID: 0000-0002-3276-4473}

National Technical University of Ukraine «Igor Sikorsky Kyiv Polytechnic Institute», Kyiv Національний технічний університет Украйни «Київський політехнічний інститут імені Ігоря Сікорськог», м. Київ, пр. Перемоги, 37, 03056

Tolbatov A.V. / Толбатов A.B. Ph.D., assistant prof. / к.т.н., доиент ORCID: 0000-0002-9785-9975

Sumy National Agrarian University, Sumy, 160 Herasym Kondratiev, Sumy, 40021 Сумський національний аграрний університет, Суми, вул. Герасима Кондратьєва, 160, 40021

Abstract. It is determined that the basis of the modern type of economic growth is the realisation of the competitive advantages, the stimulation of investment-orientated and innovative development, which is clearly connected with the spread of start-up projects. It is noted that IT companies offer both technological and organizational solutions for creating a stream of startups and their support at the initial level. Detailed key tasks solve the information systems of automatisation of innovation activity and the advantages of using modern IT tools in the management of startup projects. Analysis of a separate software sector, namely, project management systems. It was emphasized that the improvement of information technologies should be aimed at: significant increase of efficiency indicators of using information technologies; simplify access and expand the potential of software tools and widespread use of "open technologies"; creating a "friendly" interface for users; significant improvement of quality and functions of information technologies, reduction of their value. An analysis of the opportunities and limitations provided by BizSpark for information technology startups has been made. It is proved that the introduction and application of modern IT-tools for business process optimization in the sphere of startup projects gives the opportunity to fulfill the basic requirements of the business: instantaneous deployment of all processes, accurate determination of decision making process, adaptation to constant changing conditions, increase of productivity due to the efficient use of all resources, minimization of project risks, improvement of customer service level.

Keywords. innovation development, startup project, business process optimization, information technology and systems.

Formulation of the problem. The economic development of Ukraine, the perspective of building a permanent place in the European community is enriched, first with the adoption of the innovative mode of economic development. The basis of the modern type of economic growth is the development of a competitive marketplace, stimulating investment-oriented and innovative development, which is clearly connected with the spread of start-up projects as a special organizational structure aimed at the development and implementation of high-tech and innovative products. Consequently, the strategy of innovation technological development is becoming a determining factor in ensuring the effective operating of the company. Today's management is aimed at implementation of the process approach in management, it is expedient to use modern software tools to improve the efficiency of the management process. 
Analysis of recent research and publications. In addition, the range of issues related to the informational software in innovation activity is considered in the writings of such scholars as Bondar O., Bakayev O., Zgurovsky M.S. Ilyasheenko S., Kaidan L., A. Kovalev, Konovalenko I., Kravch'enko T., Kulik V., Pavlenko P.M. and others [1], [2], [3], [4], [5], [6], [7], [8], [9], [10]. Paying tribute to the theoretical and practical value of previous achievements, there is a need to explore IT-tools for optimizing business processes in such an organizational structure as startup projects.

Purpose. It should be noted that startup projects are different by the degree of radicalization of innovative products for which they are targeted. Signs such as novelty, uniqueness, and significant market power are inherent in radical innovative startup products, as opposed to incremental (improving) products that are about enhancing the individual characteristics of existing products. The analysis of the world market of startup projects in the context of the 10 largest companies, shows that the countries of treatment are USA, Canada, Australia, Hungary and the Netherlands (Table 1).

Table 1

List of leading startup projects in the world, 2018

\begin{tabular}{|c|c|c|}
\hline Position & Name of the startup project & Country \\
\hline 1 & Airbnb & USA \\
\hline 2 & Uber & USA \\
\hline 3 & Medium & USA \\
\hline 4 & Giphy & USA \\
\hline 5 & 500 panada \\
\hline 6 & Quora & USA \\
\hline 7 & Canva & Australia \\
\hline 8 & Slack & USA \\
\hline 9 & Prezi & Hungary \\
\hline 10 & WeTransfer & Netherlands \\
\hline
\end{tabular}

Consequently, innovative technological development is at the center of technological start-up projects. The future success of the project in this direction depends on the correct business modeling of the startup project. Large IT-companies offer both technological and organizational solutions for creating and maintaining startups at an initial level. According to the authors, one can distinguish the following tasks solved by the information systems of automation of innovation activity:

search and analysis of technological innovations; analysis of the novelty of specific innovation; formation and support of joint activity of teams of start-up projects; search for potential business partners; search for innovative structures to support startup projects; automation of construction of business plans of startup projects; forecasting the risks of startup projects; integration and analysis of information from different sources; competitive intelligence; formation of a consumer audience and promotion of innovations; prototyping and modeling of innovations; modeling the response of socio-economic systems to innovation management, etc.

Among the advantages of using modern IT-tools in the management of startup 
projects, namely in the management of business processes, it should be noted: their rapid and effective use, visualization and productivity; reconciliation of business and information technologies (IT); optimizing the use of all resources; fast adaptation to changes, compliance with business requirements and the growing high-tech standards in the world. The bulk of inventions in the field of information technology is used to solve the operational management tasks. The results of the research on the latest developments [4, 5, 7] indicate an increase in the possibilities of improving information technology in such areas as: a significant increase in the efficiency of the use of information technology; simplify access and expand the potential of software tools and widespread use of "open technologies"; creating a "friendly" interface for users; significant improvement of quality and functions and information technologies, reduction of their value.

According to scientists [2, 3], there can be distinguished the following methods of analysis and optimization of business processes, such as analytical methods, formally-universal methods, integrated methods of continuous improvement, benchmarking, outsourcing, instrumental methods. Optimizing the business processes of implementing a particular startup project provides the opportunity to: reduce financial costs, the length of time the task execution process and the number of inconsistencies in each of the business processes; visual presentation of the project team to a clear understanding of all the steps that need to be taken to achieve the goals; generalization of all issues related to the startup project strategy and indicators of its efficiency; possibility of introduction of the latest information technologies; high level of project management; improved interaction between team members; certification according to ISO standards; increase the investment attractiveness of the project. In the IT-market is a large amount of software for developing business processes. Developed business processes can be performed independently for one business function, and be part of corporate information systems (CIS).

A separate software sector forms project management systems that are widely represented on the market, namely:

- MicrosoftOfficeProject (Microsoft Corporation) is a comprehensive corporate project management solution that allows to manage projects of any complexity and includes a following software products;

- MS OfficeProjectStandart - an entry-level package for managing simple projects;

- MS OfficeProjectProfessional - a package for professional project management of any complexity at any level of management;

- MS OfficeProjectServer - server product used to interact with project managers in managing distributed projects;

- MS OfficeProjectWebAccess - MS Project web interface that allows project participants to access project information through InternetExplorer;

- PrimaveraProjectPlanner (companyPrimaveraInc.) - a professional version designed to automate project management processes in accordance with the requirements of PMI (ProjectManagementInstitute) and ISO standards. First of all, this package is intended for use as part of the corporate information system, although it may well work autonomously, helping to solve the tasks of scheduling network 
planning, determining the critical path, aligning resources, and other tasks of modeling projects, groups of projects, portfolios and programs;

- OpenPlan (developerWelcomSoftwareTechnology, now Deltek) provides fullscale project management, critical-path planning and optimization of enterprise-wide resource utilization $[7,10]$.

One of the most popular solutions for information technology startups is the BizSpark program. The terms of participation in BizSpark are aimed at a start-up entrepreneur or a startup company that develops a replicated software product or service. For three years the startup company is provided with: all development tools, Microsoft server and client software included in VisualStudioUltimate with a MSDN subscription (VisualStudioTeamSuite, TeamFoundationServer, ExpressionStudio, WindowsServer, SQLServer, Windows 7 and earlier versions, Office, Dynamics, etc.) to the entire team of design staff. , development and testing of software products; the right to use Microsoft server products (WindowsServer, SQLServer, OfficeSharePointPortalServer, SystemCenter, BizTalkServer, DynamicsCRM) without the restriction of their number to accommodate the created solutions and services on the Internet; provides professional technical support for Microsoft and access to MSDN resources, as well as support for the advancement of developed applications and services on the international market and in the search for international investors. Additional benefits (business consulting, hosting services, web-based accounting and reporting, assistance in promoting a product or service, legal support, investment attraction, venture fund, training, incubator, etc.); provides information about authorized partners in the BizSpark community.

There are a number of limitations (the prohibition of the use of BizSpark licenses for services such as hosting, website design, system integration, outsourcing software development), as well as requirements to the company (it should be private, registered for no more than three years therefore (individuals who are in the process of registering a legal entity or have not even begun this process can also participate in the program) and have an annual income of no more than $\$ 500,000$, is offset by the availability of a wide range of effective tools for creating and deploying business. By the end of three years after registration with the BizSpark program, the participant has the opportunity to save the software received under the program and purchase a subscription to Microsoft software updates on special terms.

\section{Conclusions.}

The review of software products allows to generalize that their widespread use will improve the quality of the management of the startup-projects, the effectiveness of business process management and the formation of a successful standard of the company, which is the basis for creating internal rules and procedures for the team of the project, preparation and continuous training of staff, as well as solving tasks for automating business processes. Implementation and application of modern IT-tools for optimizing business processes in the field of startup projects gives the opportunity to fulfill the basic requirements of the business: instantaneous deployment of all processes, accurately determine decision making, adaptation to constant changing conditions, increase of productivity at the expense of efficient use of all resources, minimization of design risks, improvement of customer service level. The 
development of further research in this direction should be aimed at substantiating a set of actions, resources and opportunities for the introduction of software products in the management of startup projects.

\section{References:}

1. Tolbatov A.V. Development concept modeling of business processes of modern industrial enterprises in terms of theoretical and legal approaches to the analysis information security / A.V. Tolbatov, V.A. Tolbatov // International scientific-technical magazine Measuring and computing devicesin technological processes. - Khmel'nyts'kyy, 2017. - №1 - P.196-199.

2. Pavlenko P.M. Information technology for data exchange between production purpose integrated automated systems / P.M. Pavlenko, A.V. Tolbatov, V.V. Tretiak, S.V. Tolbatov, V.A. Tolbatov, H.A. Smolyarov, O.B. Viunetko // International scientific-technical magazine Measuring and computing devicesin technological processes. - Khmel'nyts'kyy, 2016. - №1 -P.86-89.

3. Tolbatov A.V. Functional modeling - methodological basis for invertigation of business processes at indusrtial enterprises / A.V. Tolbatov, S.V. Tolbatov, O.O. Tolbatova, V.A. Tolbatov // International scientific-technical magazine Measuring and computing devicesin technological processes. - Khmel'nyts'kyy, 2017. - №3 P.186-189.

4. Tolbatov A.V. Technology of acceptance of administrative decisions on the stage of technical preproduction / P.M. Pavlenko, V.V. Tretiak, A.V. Tolbatov, G.A. Smolarov, V.A. Tolbatov // International scientific-technical magazine Measuring and computing devices in technological processes, Khmelnitsky, 2018, №1 (61) P.7679 .

5. Chuprina M.A. Information and analytical sustention of the transformation process of the management system of development of the ukrainian industry strategic potential / M.A. Chuprina, I.A. Shekhovtsova, A.V. Tolbatov // International scientific-technical magazine Measuring and computing devices in technological processes, Khmelnitsky, 2018, №1 (61) P.114-118.

6. Tolbatov A.V. Innovative technologies in power engineering / Viunenko O.B., Tolbatov A.V., Tolbatov V.A. // International periodic scientific journal Modern engineering and innovative technologies Issue №3 Vol.1 March 2018 P. 156159.

7. Tolbatov A.V. Using blockchain technology for E-learning / A.V. Tolbatov, S.V. Agadzhanova, O.B. Viunenko, V.A. Tolbatov // International scientifictechnical magazine Measuring and computing devices in technological processes, Khmelnitsky, 2018, №1 P.110-113.

8. Tolbatov A. Data representing and processing in expert information system of professional activity analysis / Zaritskiy O., Pavlenko P., Tolbatov A. / 2016 Modern Problems of Radio Engineering, Telecommunications and Computer Science, Proceedings of the13thConf. TCSET2016-Lviv-Slavske, 2016.-P.831-833.

9. Tolbatov A. Theoretical bases, methods and technologies of development of the professional activity analytical estimation intellectual systems / Zaritskry, O., Pavlenko, P., Sudic, V., Tolbatov, A., Tolbatova, O., Tolbatov, V., Viunenko, O. I 
2017 2nd International Conference on Advanced Information and Communication Technologies, AICT 2017 - Proceedings - Lviv, 2017.-P.101-104.

10. Tolbatov A.V. Information technology architecture development for work complexity assessment alghoritms implementation / A.V. Tolbatov, V.A. Tolbatov, S.V. Tolbatov //Modern scientific research and their practical application. - Volume J21410. November 2014. - P. 166-170.

Анотація. Визначено, що в основі сучасного типу економічного зростання лежить реалізайія потениійних конкурентних переваг, стимулювання інвестииійно-орієнтованого та інновачійного розвитку, що безумовно, зв'язано із поширення стартап-проектів. Зазначено, що IT-компанії пропонують як технологічні, так $і$ організаційні рішення для формування потоку стартапів та їх підтримки на початковому рівні. Деталізовані ключові завдання, які вирішують інформаційні системи автоматизації інноваційної діяльності та переваги використання сучасних IT-інструментів в менеджменті стартап-проектів. Проведено аналіз окремого сектору програмного забезпечення, а саме, систем управління проектами. Підкреслено, що вдосконалення інформаиійних технологій повинне бути спрямоване на: значне підвищення показників ефективності використання інформаиійних технологій; спрощення доступу $i$ розиирення потенщійних можливостей засобів програмного забезпечення $і$ широкого застосування «відкритих технологій»; створення «дружнього» інтерфейсу для користувачів; істотне покращення якості та функиій $i$ інформаиійних технологій, зниження їх вартості. Здійсно аналіз можливостей та обмежень, які надаються програмою BizSpark для стартапів у сфері інформаиійних технологій. Доведено, що впровадження та застосування сучасних IT-інструментів оптимізаиії бізнес-прочесів у сфері стапртап-проектів дає можливість виконувати основні вимоги бізнесу: миттєве розгортання всіх процесів, точно визначати постановку рішень, адаптацію до постійних змінних умов, підвищення продуктивності за рахунок ефективного використання всіх ресурсів, мінімізацію проектних ризиків, покращення рівня обслуговування клієнтів.

Ключові слова: інновачійний розвиток, стартап-проект, оптимізаиія бізнес-процесів, інформаційні технологі та системи.

(C) Chuprina M.O. 